\title{
Model Diseminasi Informasi Komunikasi Kesehatan Masyarakat Pedesaan di Kabupaten Bandung Barat
}

\author{
Saleha Rodiah ${ }^{1}$, Agung Budiono ${ }^{2}$, dan Asep Saeful Rohman ${ }^{3}$ \\ Universitas Padjadjaran
}

\begin{abstract}
ABSTRAK
Akses masyarakat terhadap informasi kesehatan belumlah merata, untuk dapat mewujudkan kemandirian masyarakat di bidang kesehatan dilakukan kegiatan promosi kesehatan sebagai upaya peningkatan partisipasi masyarakat di bidang kesehatan, khususnya di pedesaan Kabupaten Bandung Barat. Untuk itu perlu diketahui bagaimana model diseminasi informasi kesehatan masyarakat pedesaan ditinjau dari peran komunikator, manajemen pesan serta khalayaknya. Metode yang digunakan yakni studi kasus dengan pendekatan kualitatif, dengan teknik pengumpulan datanya berupa pengamatan langsung ke lapangan, wawancara tidak terstruktur, Focus Group Discussion (FGD), dan studi pustaka. Informan penelitian ini berjumlah 7 (tujuh) orang, dipilih secara purposif. Hasil penelitiannya adalah komunikator diseminasi informasi kesehatan melibatkan berbagai pihak dengan sistem pemberdayaan berjenjang, hingga subjek terakhirnya adalah warga masyarakat. Agen pemberdaya sebagai komunikator diseminasi informasi menjalankan peran sebagai fasilitator, motivator dan mediator. Strategi manajemen pesan yang digunakannya adalah pendidikan dan promosi kesehatan menuju perubahan perilaku yang berwawasan kesehatan. Penyampaian informasi kesehatan melalui sosialisasi dan penyuluhan ditujukan pada perangkat desa dan masyarakat. Informasi yang bersifat ajakan (persuasif) juga secara aktif dilakukan agar masyarakat dapat meningkatkan kualitas kesehatannya. Diseminasi informasi akan berhasil apabila komunikator dapat menganalisa khalayak sasarannya, yakni mengidentifikasi sasaran berdasarkan sosiodemografi, kebutuhan informasi kesehatan serta cara-cara pemilihan akses informasi.
\end{abstract}

Kata-kata Kunci: Informasi kesehatan; kabupaten bandung barat; model diseminasi; pemberdayaan masyarakat; promosi kesehatan

\section{The Dissemination Model Of Health Communication Information in Rural Community at West Bandung Regency}

\begin{abstract}
Public access to health information has not been evenly distributed, in order to realize community independence in the health sector health promotion activities are carried out as an effort to increase community participation in the health sector, especially in rural West Bandung District. Therefore, it is necessary to know how the model of dissemination of health information for rural communities in terms of the role of communicators, message management and audiences. The method used is a case study with a qualitative approach. Data collection techniques used were direct observation to the field, in-depth interviews, Focus Group Discussion (FGD), and literature studies. The informants of this study were 7 (seven) people, purposively selected. The results of his research are communicators of health information dissemination involving various parties with tiered empowerment systems, so that the final subject is citizens. Empowering agents as communicators of information dissemination carry out roles as facilitators, motivators and mediators. Health workers carry out message management strategies towards behavior change through means of health education and promotion. Providing health information includes socialization and counseling to village officials and community members. Persuasive information is also actively conducted so that the community can improve the quality of their health. Information dissemination will succeed if the communicator can analyze the target audience, namely identifying targets based on sociodemography, health information needs and ways of selecting information access.Keywords: Gay Students; Homosexual; LGBT; Personal Identity; Social Construction
\end{abstract}

Keywords: Community empowerment; dissemination model; health information; health promotion; west bandung regency

Korespondensi: Saleha Rodiah, S.Sos., M.Si., Universitas Padjadjaran, Jl. Raya Bandung - Sumedang KM. 21, Jatinangor, Sumedang, Jawa Barat, Kode Pos 45363, Email: saleha.rodiah@unpad.ac.id 


\section{PENDAHULUAN}

Saat ini, informasi kesehatan tersedia dalam beragam sumber, yaitu majalah, radio, koran, televisi, perpustakaan, Internet, dan lain sebagainya. Informasi tersebut mempunyai peran yang penting bagi masyarakat untuk memperoleh pencapaian yang lebih baik di berbagai bidang kehidupan, seperti pekerjaan, pendidikan dan kesehatan. Untuk itu upaya menjadi anggota masyarakat yang melek (literat) informasi kesehatan menjadi hak setiap warga negara. Seperti yang tercantum dalam Undangundang Kesehatan No. 36 Tahun 2009, Pasal 7 bahwa: Setiap orang berhak untuk mendapat informasi dan edukasi tentang kesehatan yang seimbang dan bertanggung jawab. Dikuatkan pula dengan Peraturan Pemerintah Republik Indonesia Nomor 46 tahun 2014 tentang Sistem Informasi Kesehatan yang menyebutkan: Informasi Kesehatan adalah Data Kesehatan yang telah diolah atau diproses menjadi bentuk yang mengandung nilai dan makna yang berguna untuk meningkatkan pengetahuan dalam mendukung pembangunan kesehatan.

Salah satu penentu kondisi daerah adalah Indeks Pembangunan Manusia (IPM) ditinjau dari tingkat kesehatan masyarakat yang juga representasi tingkat kesejahteraan masyarakat suatu daerah. Indeks Pembangunan Manusia bidang kesehatan Kabupaten Bandung Barat pada Tahun 2013 adalah 73,84 poin yang berada di atas IPM Jawa Barat 72,99 poin. Namun pada Tahun 2014 menurun menjadi 73,88 poin dan berada di bawah IPM bidang kesehatan Jawa Barat sebesar 74,01 poin. Berdasar hal tersebut penelitian ini memfokuskan pada kegiatan diseminasi informasi kesehatan yang dilakukan di wilayah pedesaan Kabupaten Bandung Barat.

Beberapa rujukan penelitian yang dilakukan terdahulu tentang diseminasi informasi kesehatan, yaitu penelitian yang dilakukan Agung Dwi Laksono dan Ratna Dwi Wulandari (2011) berjudul: Analisis Potensi Penyebaran Informasi Kesehatan melalui Jejaring Sosial: Studi Kasus pada 'Forum Jejaring Peduli AIDS.' Penelitian ini mengukur efektivitas penyebaran informasi, mengingat penyebaran informasi melalui media jejaring sosial tidak terbatas wilayah administratif. Metode yang digunakan adalah content analysis. Anggota Forum Jejaring Peduli AIDS ini berasal dari 20 negara. Anggota yang berdomisili di luar negeri ini pada umumnya adalah warga negara Indonesia yang bekerja di luar negeri, sehingga menggunakan Bahasa Indonesia. Kajiannya membahas tren jumlah pengakses Halaman Forum Jejaring Peduli AIDS, tren total interaksi, kualitas interaksi Posting, serta tema posting. Penelitian ini menggunakan Teori dari Rogers yang diaplikasi tahapannya dalam proses difusi inovasi pada Forum Jejaring Peduli AIDS, yaitu: 1) Knowledge, seluruh anggota forum bila sudah membaca posting tertentu pasti akan sadar dan tahun tentang informasi tersebut; 2) Persuassion, Individu yang sudah mendapat informasi akan menunjukkan favorable dan unfavorable. Sikap unfavorable terjadi karena adanya perbedaan pandangan mengenai metode pencegahan AIDS; 3) Decision, secara substansi $100 \%$ anggota dapat menerima informasi yang tersebar dalam forum jejaring peduli AIDS; 4) Implementation, Berdasarkan komentar atau posting terlihat bahwa tidak ada anggota yang berisiko AIDS, bahkan ada yang aktif mengikuti organisasi yang peduli AIDS; 5) Confirmation, khusus tahapan ini belum terdeteksi secara baik dalam forum ini sebab belum secara khusus dilakukan evaluasi. (Laksono \& Wulandari, 2011).

Selanjutnya penelitian Ratnasari yang berjudul Komunikasi Kesehatan: Penyebaran Informasi Gaya Hidup Sehat. Penelitian ini memfokuskan pada karakteristik pesan, saluran komunikasi, dan rentang waktu penyebaran gagasan gaya hidup sehat dengan menerapkan food combining sebagai inovasi baru di bidang kesehatan masyarakat. Hasilnya adalah: 1) informasi kombinasi makanan serasi (food combining) sebagai inovasi baru di bidang komunikasi kesehatan tidak terlepas dari pandangan masyarakat, antara lain terkait dengan faktor keuntungan relatif, kompabilitas dan kompleksitas; 2) Pada saluran komunikasi, ahli nutrisi food combining menggunakan panduan antara kmunikasi pribadi, komunikasi kelompok dan komunikasi massa dalam menyebarkan informasi kesehatan; 3) dalam penyebaran informasi food combining sebagai inovasi baru memerlukan waktu yang cukup lama dan upaya kuat konsultan nutrisi atau komunikasi kesehatan agar masyarakat dapat merasakan manfaatnya. (Ratnasari, 2008).

Perbedaan dengan penelitian sebelumnya adalah dalam penelitian ini mengkaji diseminasi (penyebaran) informasi kesehatan 
ditinjau dari teori komunikasi kesehatan (health Communication), yang meliputi unsur-unsur komunikator kesehatan, komunikan, pesan, media, efek dan konteks komunikasi kesehatan (Liliweri, 2013). Selanjutnya terkait dengan diseminasi informasi sebagai bentuk dan proses komunikasi, Hamad mengatakan pembahasan diseminasi informasi menggunakan $5 \mathrm{~W}$ dan 1H. Setidaknya, unsur komunikator (who), pesan (what) dan khalayak (whom) merupakan variabel penelitian yang penting dicermati dalam studi diseminasi informasi. Untuk itu penelitian ini mempunyai 3 (tiga) tujuan penelitian, yaitu mengetahui peran komunikator, manajemen pesan serta khalayak dalam kegiatan diseminasi informasi kesehatan masyarakat pedesaan di Bandung Barat.

Selain itu dari hasil wawancara dengan Kasie Pemberdayaan Masyarakat Desa (PMD) Kecamatan Ngamprah Kabupaten Bandung Barat menyebutkan bahwa "untuk masyarakat Ngamprah tingkat partisipasi masyarakatnya dalam mengikuti kegiatan posyandu sangat baik, namun masih terbatasnya pemerataan pembangunan kesehatan." Hal ini menunjukkan perluupaya optimalisasi peran masyarakat dalam pembangunan kesehatan. Di mana Kecamatan Ngamprah Bandung Barat mempunyai 2 Puskesmas, yaitu: Puskesmas Cimareme dan Puskesmas Ngamprah. Dari 6 (enam) desa yang termasuk wilayah kerja Puskesmas Cimareme, yaitu: Pakuhaji, Gadobangkong, Cilame, Cimareme, Margajaya dan Tanimulya, terdapat satu desa yang pernah masuk dalam kategori desa berisiko sangat tinggi di bidang sanitasi, yaitu Desa Pakuhaji.

Kegiatan penyebaran informasi kesehatan sebagai bagian penting dalam mempercepat pencapaian tujuan pembangunan kesehatan. Sebagai kajian dalam ilmu informasi dan komunikasi, proses penyebaran atau diseminasi informasi yang berhasil akan mampu memberikan efek di segala bidang. Untuk itu diseminasi informasi perlu ditunjang oleh penggunaan unsur-unsur komunikasi yang tepat dalam meningkatkan tingkat kualitas kesehatan masyarakat serta mencapai kesehatan paripurna sesuai amanat Undang-undang pada Pasal 1 bahwa:

Kesehatan adalah keadaan sehat, baik secara fisik, mental, spritual maupun sosial yang memungkinkan setiap orang untuk hidup produktif secara sosial dan ekonomis.
Berdasarkan uraian di atas, maka diperoleh rumusan masalah penelitian ini, yaitu "Bagaimana Model Diseminasi Informasi Komunikasi Kesehatan Masyarakat Pedesaan di Kabupaten Bandung Barat?’.

\section{METODE PENELITIAN}

Metode penelitian yang digunakan adalah kualitatif dengan pendekatan studi kasus. Pemilihan metode penelitian kualitatif dengan pendekatan studi kasus sesuai untuk meneliti tentang Diseminasi Informasi Kesehatan Masyarakat Pedesaan di Kabupaten Bandung Barat. Penelitian kualitatif menggunakan analisis manusia sebagai instrumen penelitian, menggunakan analisis induktif, mengarahkan tujuan penelitian pada upaya mendapatkan teori dasar, bersifat deskriptif, serta lebih mengutamakan proses daripada hasil. Menurut Yin, pendekatan studi kasus merupakan strategi yang cocok bila pokok pertanyaan suatu penelitian berkenaan dengan bagaimana dan mengapa serta peneliti hanya memiliki sedikit kesempatan untuk dapat mengontrol peristiwa-peristiwa yang akan diteliti dan fokus penelitiannya pada fenomena masa kini (Yin, 2008).

Kasus yang dipelajari adalah masih terbatasnya pemerataan pembangunan kesehatan, untuk itu perlu dikaji bagaimana kegiatan diseminasi informasi kesehatan melalui pemberdayaan masyarakat, yang dilakukan di Desa Pakuhaji Kecamatan Ngamprah Kabupaten Bandung Barat, sebagai desa yang semula masuk kategori desa tertinggal perlahan berkembang di bidang kesehatan melalui kegiatan pemberdayaan masyarakat. Sehingga dapat dibuat model diseminasi informasi kesehatan yang efektif agar dapat diakses masyarakat secara luas dan bermanfaat dalam mengatasi masalah kesehatannya.

Dalam penelitian ini, teknik pengumpulan datanya menggunakan pengamatan langsung ke lapangan, wawancara tidak terstruktur, Focus Group Discussion (FGD), dan studi pustaka. Objek dalam penelitian adalah aktivitas diseminasi informasi kesehatan yang dikaji di Desa Pakuhaji Kecamatan Ngamprah Kabupaten Bandung Barat terkait dengan peran komunikator, khalayak dan manajemen pesan. Sedangkan subjek penelitiannya sebanyak 7 (tujuh) orang, dipilih secara purposif yang 
terlibat langsung dalam kegiatan penyebaran informasi kesehatan melalui pemberdayaan masyarakat, terdiri dari: Kepala Seksi Pemberdayaan Masyarakat Desa (PMD) Kecamatan Ngamprah; Promotor Kesehatan Puskesmas Cimareme; Kaur Kesejahteraan Desa Pakuhaji; Ketua Tim Penggerak PKK, Bidan Desa dan Kader PKK.

Dalam penelitian kualitatif, analisis data dilakukan selama proses di lapangan bersama dengan kegiatan pengumpulan data (Sugiyono, 2010). Disebutkan pula bahwa kegiatan analisis data kualitatif dilakukan dengan cara interaktif dan langsung serta terus menerus hingga selesai, sampai datanya sudah jenuh. Peneliti menggunakan 3 (tiga) tahap analisis data, yaitu: reduksi data, penyajian data, serta penarikan kesimpulan dan verifikasi.

\section{HASIL DAN PEMBAHASAN}

Pakuhaji adalah salah satu desa di Kecamatan Ngamprah, Kabupaten Bandung Barat yang semula merupakan bagian dari Desa Tani Mulya. Wilayah ini merupakan daerah dataran yang bergelombang dan berbukit di lereng gunung dengan ketinggian 700 meter diatas permukaan laut. Desa Pakuhaji berdiri mulai Tahun 1989 sebagai perluasan dari Desa Tani Mulya. Semula Desa Pakuhaji masuk kategori Desa Tertinggal, saat ini sudah dalam kategori Desa Berkembang.

Program-program kesehatan masyarakat di Desa Pakuhaji sampai saat ini telah berjalan dengan baik, meskipun masih terdapat keterbatasan dalam hal sarana maupun kelembagaan. Hal tersebut tidak terlepas dari kerjasama berbagai pihak, antara lain motivasi dari Dinas Kesehatan Bandung Barat, Puskesmas Cimareme serta pelaksana di tingkat desa, yaitu bidan desa dan para kader kesehatan. Bantuan serta pembinaan dari Puskesmas Cimareme sebagai penanggung jawab program kesehatan untuk wilayah di Desa Pakuhaji serta para kader yang ada, program kesehatan mulai meningkat akselerasinya. Sebagaimana hasil wawancara dengan Promotor Kesehatan Kecamatan Cimareme, Ibu Sri Sariningsih, yaitu:

Salah satu indikator kemajuan Desa Pakuhaji di bidang kesehatan dapat dilihat dari data tentang penentuan area risiko sanitasi untuk Kabupaten Bandung Barat,
Desa Pakuhaji pada Tahun 2013 masuk kategori risiko sangat tinggi terkait dengan sanitasi, yang dinilai melalui data sekunder, persepsi SKPD dan studi Enviromental Health Risk Assesment (ERHA) dan data terbaru 2018 menyebutkan Desa Pakuhaji masuk kategori risiko sedang.

Beberapa kegiatan yang berkaitan dengan kesehatan sedang dan telah dilaksanakan di Desa Pakuhaji dalam 2 tahun terakhir. Hal ini ditandai dengan meningkatnya peran kader untuk melakukan sosialisasi melalui program program layanan kesehatan dasar, kesehatan lingkungan, aktivitas posyandu serta kegiatan senam sehat yang dilaksanakan tingkat RW . Adakalanya untuk merangsang agar kegiatan tersebut memiliki kualitas layanan yang tinggi maka para kader dengan bimbingan dari Puskesmas Cimareme, mengikutsertakan beberapa program kesehatan mereka untuk mengikuti lomba baik di tingkat Kecamatan maupun Kabupaten. Sampai saat ini program kesehatan di Desa Pakuhaji belum pernah memenangkan lomba tersebut sampai juara pertama, tetapi walaupun demikian semangat para kader kesehatan untuk berusaha mencapai tingkat prestasi yang tinggi terus menerus mereka pelihara. Hal ini dapat dilihat pada tabel 1.

Program kesehatan desa dilaksanakan di bawah bimbingan Puskesmas Cimareme yang menugaskan beberapa tenaga medisnya untuk melakukan supervisi, monitoring serta bimbingan sehingga program tersebut berjalan di 12 RW dan 40 RT. Kegiatan ini dibantu oleh para kader kesehatan yang tersebar di masing masing RT dan RW. Pelayanan kesehatan dasar merupakan kegiatan yang menjadi pondasi bagi tercapainya perilaku hidup sehat. Oleh karena itu bentuk layanan ini banyak didominasi oleh pemantauan serta penanggulangan masalah kesehatan pada ibu dan anak. Hal ini dapat dilihat dari tabel 2. Untuk nomor 4 terkait pemberian oralit merupakan pelayanan dasar yang disertakan, sebab Desa Pakuhaji termasuk kategori desa yang memiliki penilaian sanitasi dalam rentang kategori sedang (sebelumnya masuk kategori risiko tinggi), yang rawan terjangkit penyakit diare. Untuk itu penguatan partisipasi masyarakat dalam bidang kesehatan lingkungan mendapatkan prioritas utama.

Upaya Kesehatan Berbasis Masyarakat 
Tabel 1 Kegiatan Program Kesehatan

\begin{tabular}{|c|c|c|}
\hline No & Program & Kegiatan \\
\hline 1 & $\begin{array}{l}\text { Pelayanan Kesehatan } \\
\text { Dasar }\end{array}$ & $\begin{array}{l}\text { Klinik Ibu \& Anak } \\
\text { Layanan Keluarga Berencana } \\
\text { Imunisasi } \\
\text { Penanggulangan Diare }\end{array}$ \\
\hline 2 & $\begin{array}{l}\text { Upaya Kesehatan } \\
\text { Berbasis Masyarakat } \\
(\mathrm{UKBM})\end{array}$ & $\begin{array}{l}\text { Posyandu } \\
\text { Tabulin } \\
\text { Dasolin } \\
\text { PAUD } \\
\text { Donor Darah } \\
\text { Ambulance }\end{array}$ \\
\hline 3 & $\begin{array}{l}\text { Sistem Kesiapan } \\
\text { Penanggulangan } \\
\text { Kegawatan \& Bencana }\end{array}$ & $\begin{array}{l}\text { Pengadaan Sarana \& Prasarana } \\
\text { Pelatihan \& Simulasi }\end{array}$ \\
\hline 4 & Kesehatan lingkungan & $\begin{array}{l}\text { Pendataan \& perlindungan sarana air bersih dan sanitasi. } \\
\text { Pelaksanaan Program K3 }\end{array}$ \\
\hline 5 & $\begin{array}{l}\text { Perilaku hidup bersih } \\
\text { dan sehat (PHBS) }\end{array}$ & $\begin{array}{l}\text { Penyuluhan ASI, Gizi, Penyakit, narkoba, jamban sehat \& rumah } \\
\text { sehat }\end{array}$ \\
\hline 6 & Kegiatan lain & $\begin{array}{l}\text { Pengajian } \\
\text { Dasa wisma } \\
\text { Senam sehat }\end{array}$ \\
\hline
\end{tabular}

Sumber: Dokumen Desa Pakuhaji tentang Program Kesehatan Desa, 2016

Tabel 2 Pelayanan Kesehatan Dasar

\begin{tabular}{cclc}
\hline No & \multicolumn{1}{c}{ Kegiatan } & \multicolumn{1}{c}{ Uraian } & Kegiatan \\
\hline 1 & Klinik Ibu dan Anak & Pelayanan untuk Ibu hamil, bersalin, & \\
& & Neonatus, kematian Ibu/bayi & \\
2 & Layanan Keluarga & Peserta aktif/pasif & $1242 / 113$ \\
& Berencana & Implant/IUD & $53 / 36$ \\
& & MOW/MOP & $22 / 11$ \\
3 & Imunisasi & BSG /Polio & $12 / 10$ \\
& & Campak/TT & $11 / 6$ \\
& & Hepatitis A/B/C & $8 / 8 / 10$ \\
& & & \\
& & & \\
& & &
\end{tabular}

Sumber: Dokumen Desa Pakuhaji tentang Program Kesehatan Desa, 2016 
merupakan program kesehatan yang menumbuhkembangkan kesadaran masyarakat agar pola hidup sehat merupakan terjangkit penyakit diare. Untuk itu penguatan partisipasi masyarakat dalam bidang kesehatan lingkungan mendapatkan prioritas utama.
Upaya Kesehatan Berbasis Masyarakat merupakan program kesehatan yang menumbuhkembangkan kesadaran masyarakat agar pola hidup sehat merupakan bagian dari aktivitas sehari hari. Hal ini ditandai dengan kesadaran para ibu untuk secara rutin

Tabel 3 Upaya Kesehatan Berbasis Masyarakat (UKBM) Desa Pakuhaji

\begin{tabular}{clll}
\hline No & \multicolumn{1}{c}{ Sarana/Kegiatan } & \multicolumn{1}{c}{ Jumlah } & \multicolumn{1}{c}{ Keterangan } \\
\hline 1 & Posyandu Pratama & 2 buah & 1 posyandu akan menjadi \\
2 & Posyandu Madya & 10 buah & $\begin{array}{l}\text { posyandu Mandiri } \\
\end{array}$ \\
3 & Posyandu Mandiri & 0 & \\
4 & Peserta Posyandu Aktif/Pasif & $156 / 19$ anak & \\
5 & Tabulin & $11 \mathrm{RW}$ & \\
6 & Dasolin & $12 \mathrm{RW}$ & 53 yang aktif \\
7 & PAUD & 2 buah & \\
8 & Peserta Donor Darah & 100 orang & \\
9 & Taman Obat Keluarga & $1786 \mathrm{KK}$ & \\
10 & Mobil Ambulance & 1 buah & \\
\hline
\end{tabular}

Sumber: Dokumen Desa Pakuhaji tentang Program Kesehatan Desa, 2016

\section{Tabel 4 Kesehatan Lingkungan}

\begin{tabular}{clll}
\hline No & \multicolumn{1}{c}{ Kegiatan/Sarana } & \multicolumn{1}{c}{ Uraian } & Keterangan \\
\hline 1 & Sarana air bersih & 3 buah & \\
2 & Sumur Gali & 87 buah & \\
3 & Pelanggan PDAM & $250 \mathrm{KK}$ & \\
4 & Septic Tank Dangkal & 0 & \\
5 & Pompa air listrik & $39 \mathrm{KK}$ & Berikut program \\
6 & Penggunaan mata air untuk rumah tangga & $1571 \mathrm{KK}$ & perlindungannya \\
& & & \\
7 & Penggunaan mata air untuk masjid & 14 buah & \\
8 & Penggunaan mata air untuk sekolah & 2 buah & \\
9 & Penggunaan mata air untuk Hotel/ wisma & 1 buah & \\
10 & Penggunaan mata air untuk kolam renang & 1 buah & \\
11 & Penggunaan mata air untuk air isi ulang & 3 buah & \\
12 & Penngunaan mata air untuk rumah makan & 4 buah & \\
13 & Kegiatan Jumat bersih & 1 minggu sekali & \\
14 & Kegiatan Jumantik & 1 minggu sekali & \\
15 & Tempat pengelolaan sampah sementara & 1 buah & \\
& & &
\end{tabular}

Sumber: Dokumen Desa Pakuhaji tentang Program Kesehatan Desa, 2016 
mengikutsertakan anak mereka di layanan posyandu, ikut serta dalam program donor darah serta kesadaran untuk memiliki Taman Obat Keluarga (Toga). Data Upaya Kesehatan Berbasis Masyarakat di Desa Pakuhaji dapat dilihat pada tabel 3. Kesehatan lingkungan merupakan program utama puskesmas yang berusaha menciptakan kondisi lingkungan yang dapat menopang keseimbangan ekologi yang harmoni antara manusia dan lingkungannya guna mencapai kualitas hidup manusia yang sehat serta bahagia. Program ini mencakup hal hal yang berkaitan dengan penyehatan sumber air bersih, penyehatan lingkungan perumahan seperti sarana sanitasi dan pembuangan air limbah, penyehatan tempat pengelola makanan hingga pemantauan jentik nyamuk dan pemberantasan sarang nyamuk (PSN). Selain itu, program ini juga mencakup pemberian konsultasi tentang sanitasi dan penyakit-penyakit yang berhubungan dengan lingkungan. Di Desa Pakuhaji sebagian besar program kesehatan lingkungan sedang dan sudah dilaksanakan, sebagaimana dapat dilihat pada tabel 4 . Perilaku hidup bersih dan sehat merupakan modal dasar bagi upaya pembentukan kualitas sumber daya manusia. Perilaku masyarakat yang sehat berpengaruh terhadap kecerdasan, kemajuan serta peradaban suatu bangsa. Oleh karena itu pemerintah mendorong agar perilaku hidup sehat selalu di kampanyekan kepada masyarakat banyak agar mereka mengetahui bagaimana akibat perilaku yang tidak sehat terhadap pelbagai aspek kehidupan suatu bangsa. Beberapa kegiatan tentang hal tersebut dapat dilihat pada tabel 5. Diseminasi informasi, dalam hal ini terkait informasi kesehatan subsistem pemberdayaan masyarakat adalah bentuk serta cara penyelenggaraan upaya kesehatan, pada tingkat perorangan, kelompok, juga masyarakat luas yang terencana, terpadu, serta berkesinambungan. Upaya pemberdayaan masyarakat ini dilakukan untuk mencapai derajat kesehatan masyarakat secara maksimal. Tujuan pemberdayaan masyarakat di Desa Pakuhaji yaitu meningkatkan kemampuan masyarakat untuk berperilaku hidup sehat, mampu mengatasi masalah kesehatan secara mandiri, berperan aktif dalam setiap pembangunan kesehatan, serta dapat menjadi penggerak dalam pembangunan desa yang berwawasan kesehatan.

Kementerian Kesehatan dan aparatur dalam bidang kesehatan di daerah hal ini sebagai komunikator (source). Mereka telah berupaya mengembangkan program promosi kesehatan dalam meningkatkan derajat kesehatan. Menurut kader PKK Desa Pakuhaji Kecamatan Ngamprah, bahwa kepala desa, petugas kesehatan dari kecamatan dan bidan desa merupakan motor penggerak (agen pemberdaya) pemberdayaan kesehatan dalam menyampaikan

\section{Tabel 5 Kegiatan Perilaku Hidup Bersih Sehat (PHBS)}

\begin{tabular}{clll}
\hline No & \multicolumn{1}{c}{ Kegiatan } & \multicolumn{1}{c}{ Jumlah } & \multicolumn{1}{c}{ Keterangan } \\
\hline 1 & Penyuluhan ASI eksklusif & $1628 \mathrm{ibu}$ & \\
2 & Status keluarga sehat/tidak sehat & $1245 / 113$ & Jamban percontohan \\
3 & Penyuluhan jamban sehat & Pernah & \\
4 & Penyuluhan kadar gizi & Pernah & \\
5 & Penyuluhan larangan merokok & Pernah & \\
6 & Penyuluhan TBC/DHF/AIDS/HIV & Pernah & \\
7 & Penyuluhan Narkoba/Flu burung & Pernah & \\
8 & Penyuluhan kebencanaan & Pernah & Kegiatan pendukung \\
9 & Kelompok Dasa Wisma & Pernah & Kegiatan pendukung \\
10 & Pengajian & 15 Kegiatan perbulan & Kegiatan pendukung \\
& & untuk semua RW & \\
11 & Senam sehat & beberapa RW & \\
& & beli perbulan di & Kegiand \\
\hline
\end{tabular}

Sumber: Dokumen Desa Pakuhaji tentang Program Kesehatan Desa, 2016 
beragam informasi kesehatan pada masyarakat di Desa Pakuhaji. Informasi tersebut diperoleh dari pemerintah pusat maupun daerah sebagai sumber (source) informasi kesehatan.

Dalam panduan promosi kesehatan yang dikeluarkan oleh kementerian kesehatan, disebutkan bahwa pemberdayaan pada masyarakat diselenggarakan secara berjenjang. Proses pemberdayaan yang berjenjang umumnya diselenggarakan dengan pendekatan yang disebut pengorganisasian masyarakat atau community organization/community development. Pengorganisasian ini dimulai dari petugas kesehatan sebagai promotor kesehatan puskesmas yang mengembangkan kerjasama serta memberdayakan para tokoh masyarakat. Pengorganisasian masyarakat dapat diterapkan dalam tatanan, seperti RW/RT, sekolah dan pondok pesantren.

Dari hasil diskusi kelompok terpusat dengan warga masyarakat Desa Pakuhaji dan promotor kesehatan diperoleh keterangan bahwa para agen pemberdaya petugas kesehatan diakui masyarakat mempunyai kompetensi dan kredibitas dalam menyampaikan gagasannya dan memotivasi mereka untuk memperoleh informasi, dalam hal ini bidang kesehatan yang berguna bagi peningkatan kualitas hidup mereka. Selain itu terlihat pada perilaku sehat tokoh masyarakat dan tokoh agama sebagai acuan bagi masyarakat sekitarnya .

Dalam kegiatan pemberdayaan ini, agen pemberdaya melibatkan berbagai pihak yang mempunyai kewenangan dengan kelancaran proses diseminasi informasi kesehatan. Pelibatan masyarakat secara luas ini agar informasi kesehatan lebih akurat, efektif dengan publik yang luas. Menurut salah satu sasaran promosi kesehatan adalah kelompok sasaran Tersier (Tertiery Target) yang merupakan para pembuat kebijakan di tingkat pusat maupun daerah yang akan berpengaruh pada perilaku tokoh masyarakat(pejabat ketua RT, RW dan para sekretarisnya) dan tokoh agama (ustadz, MUI) serta masyarakat umum (Notoatmodjo, 2007). Upaya ini selaras dengan advokasi (advocacy) sebagai salah satu strategi promosi kesehatan. Rodiah, Rosfiantika, \& Yanto menyebutkan bahwa ditinjau dari ilmu komunikasi, advokasi dipandang sebagai salah satu komunikasi interpersonal maupun massa yang ditujukan pada para penentu kebijakan atau para pembuat keputusan (Rodiah, Rosfiantika, \& Yanto,
2016).

Pelibatan pemberdayaan oleh tokoh masyarakat dibimbing petugas kesehatan untuk memberdayakan kader PKK melalui penetapan Upaya Kesehatan Bersumber Daya Masyarakat (UKBM) yang umumnya dibentuk dan sesuai untuk mengatasi masalah yang terjadi di lapangan. Upaya itu, antara lain Dana Sehat, Tabungan Ibu Bersalin (Tabulin), Pondok Bersalin Desa (Polindes), Ambulan Desa, dan Pos Kesehatan Desa (Poskedes).

Sebagai contoh Pos Kesehatan Desa (Poskedes), maka materi yang diberikan antara lain berkaitan dengan observasi, cara menangani penyebab risiko, serta bagaimana menangani kegawatdaruratan. Selain itu, disampaikan pula upaya-upaya pemberdayaaan masyarakat, terutama teknik konseling individu dan konseling kelompok atau konseling keluarga. Sebagaimana disebutkan ketua tim penggerak PKK Desa Pakuhaji, bahwa pelibatan pihakpihak yang berwenang dilakukan melalui kegiatan lokakarya mini (Lokmin) yang dilakukan di tiap RW setiap bulan yang diikuti oleh para kader PKK dan kader Posyandu. Hal tersebut diamini oleh informan kader PKK, bahwa: "Selama ini puskesmas Cimareme berupaya melakukan pemberdayaan melalui lokmin (lokakarya mini) walaupun pesertanya/ kadernya masih orang-orang itu saja."

Dengan selesainya para kader dilatih, maka selanjutnya mereka bertugas memberdayakan warga masyarakat Desa Pakuhaji dengan melakukan pelayanan pada masyarakat melalui kegiatan-kegiatan UKBM (misalnya Poskedes). Biasanya para kader yang akan lebih banyak melakukan pemberdayaan masyarakat dengan menjadi fasilitator dalam kegiatan terkait proses pemecahan masalah-masalah yang sedang dihadapi individu, keluarga, atau kelompok. Sehingga para kader akan banyak melakukan kegiatan konseling individu (di Poskedes), konseling keluarga (melalui kunjungan rumah), dan konseling kelompok (Dasa Wisma). Sebagaimana disebutkan Irianto bahwa menggerakkan sumber daya masyarakat berarti bahwa setiap anggota masyarakat didorong untuk memberikan apa saja yang dimilikinya untuk memecahkan masalah yang dihadapi masyarakat (Irianto, 2014).

Sedangkan masalah-masalah yang terkait dengan media, pemecahan masalahnya diserahkan lebih lanjut kepada petugas 
kesehatan untuk membantunya. Walaupun begitu, apabila masalah terkait dengan aspek perilaku warga masyarakat, maka tetap dibina oleh kader, sehingga tercipta Pola Hidup Bersih dan Sehat (PHBS) di kalangan masyarakat.Dari pengamatan di lapangan diperoleh data bahwa di Desa Pakuhaji terdapat 3 (tiga) pesantren dan sekitar 20 mesjid yang tersebar di setiap RT. Pemberian informasi kesehatan dilakukan melalui kegiatan ceramah dan pengajian untuk ibu-ibu dan bapak-bapak yang diselenggarakan seminggu sekali dengan jadwal yang berbeda.

Pada tahap akhir dalam proses pemberdayaan masyarakat bidang kesehatan sebagai suatu siklus yang keberlanjutan (kelestarian), pihak Puskesmas dan para pemuka masyarakat melakukan kegiatan Dukungan, Pemantauan serta Bimbingan (DPB). Dalam langkah ini, puskesmas (dengan dibantu Dinas Kesehatan Kabupaten/Kota) melaksanakan strategi promosi kesehatan yaitu bina suasana dan advokasi-advokasi.

Menurut Notoatmodjo secara bertahap tujuan pemberdayaan masyarakat di bidang kesehatan adalah: 1) tumbuhnya kesadaran, pengetahuan, pemahaman akan kesehatan bagi individu, kelompok atau masyarakat. Masyarakat yang mampu memelihara dan meningkatkan kesehatan melalui proses belajar kesehatan yang dimulai dengan perolehan informasikesehatan.;2) timbulnya kemauan atau kehendak sebagai lanjutan dari kesadaran dan pemahaman tentang kesehatan, yang terkadang disebut sebagai sikap. Faktor dalam mendukung berlanjutnya kemauan, adalah sarana prasarana pendukung tindakan tersebut; 3) Timbulnya kemampuan masyarakat di bidang kesehatan, yang berarti masyarakat secara individu juga kelompok telah mampu mewujudkan kemauan dalam bentuk perilaku sehat (Notoatmodjo, 2007). Sehingga individu, kelompok atau masyarakat yang sudah mampu memfasilitasi kebutuhan-kebutuhan sarana dan prasarana kesehatan adalah masyarakat yang telah mandiri di bidang kesehatan. Tinjauan mengenai peran komunikator dalam upaya menumbuhkan sikap

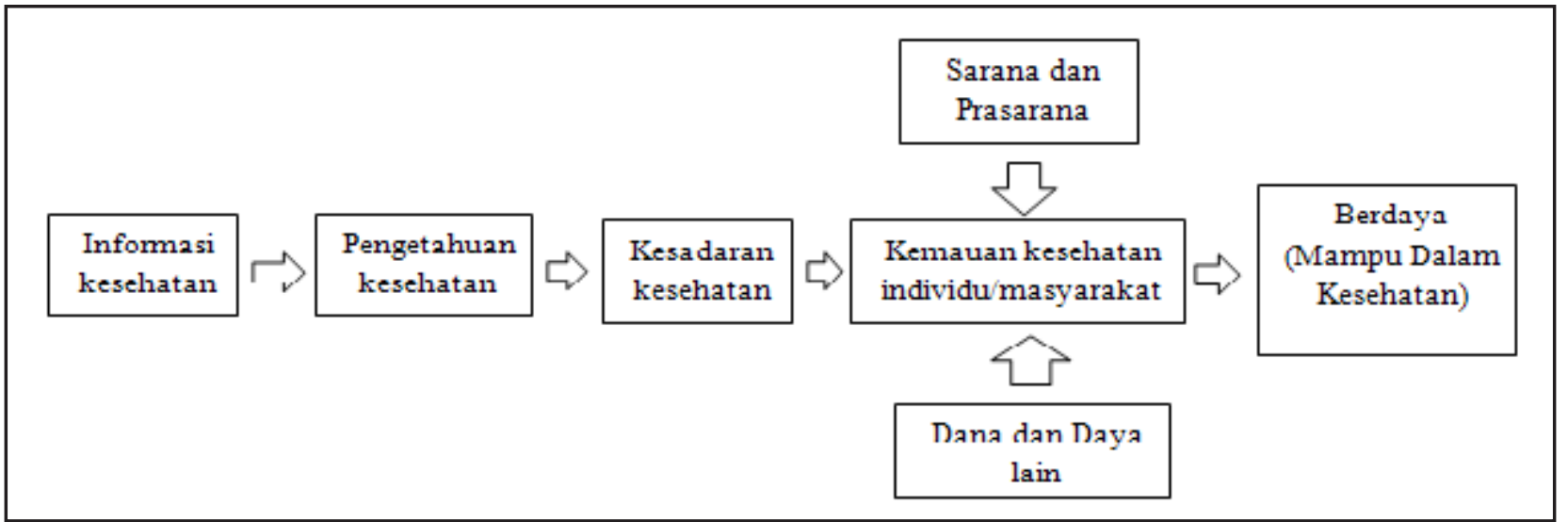

Sumber: Notoatmodjo, 2007

\section{Gambar 1 Proses Pemberdayaan Masyarakat Berbasis Informasi Kesehatan}

berdaya pada warga masyarakat di bidang informasi kesehatan yaitu sebagai penghubung (fasilitator) untuk memberikan informasi terkait dengan jadwal posyandu, dan lainlain. Terkait dengan peran komunikator yang menyebutkan bahwa keahlian komunikator dalam menyampaikan pesan tentang suatu penyakit telah dapat menambah pengetahuan masyarakat dan menumbuhkan kepercayaan masyarakat pada komunikator (konselor) serta kesediaan untuk menjauhi perilaku penyakit yang berisiko seperti narkoba dan seks bebas (Niftah \& Rahmat, 2017). Memberikan pengarahan tentang kesehatan, mendampingi masyarakat yang sakit, memberikan dorongan spiritual (pengobatan melalui air do'a oleh ustadz). Hal ini dilakukan karena masih ada warga Desa Pakuhaji yang percaya pengobatan non medis, untuk itu tokoh agama dilibatkan dalam pemberdayaan masyarakat bidang kesehatan.

Kebiasaan masyarakat ini dikuatkan dengan pendapat salah satu informan: "Tokoh masyarakat sangat antusias pada pemberdayaan karena beliau-beliau menjadi panutan dan ajakan/himbauannya selalu didengar warga. Tokoh agama lebih berperan, contohnya mengajak ibu-ibu dan anak-anak untuk mengaji, 
sehingga dapat menyisipkan pesan komunikasi kesehatan dalam materi pengajian. Disebutkan Wahyudi bahwa salah satu elemen komunikasi kesehatan, yaitu komunikator yang harus mempunyai kredibilitas yang sesuai dengan kebutuhan khalayak (Wahyudi, 2009). Tokoh agama di Desa Pakuhaji dianggap memiliki pemahaman mengenai sasaran komunikasi sebagai kemampuan yang sangat dibutuhkan dalam kegiatan diseminasi informasi kesehatan.

Petugas kesehatan terus mendukung upaya para kader dan tokoh masyarakat melalui pelayanan Puskesmas, baik pelayanan di dalam gedung maupun pelayanan di masyarakat. Di samping itu, sewaktu-waktu petugas kesehatan harus datang langsung ke masyarakat menginisasiasi warga dan membantu kader, melalui kunjungan ke rumah (pelayanan di masyarakat). Bekerja sama dengan petugas promosi kesehatan dari Kabupaten/Kota, Puskesmas juga terus melakukan strategi bina suasana (seperti: ceramah, pemasangan) di RW/RT yang bersangkutan. Para kader PKK dan Posyandu berperan sebagai motivator yaitu bergerak memotivasi warga dalam pendampingan warga masyarakat untuk sembuh dari penyakit tertentu seperti tubercolosis (TBC), dengan cara mengingatkan jadwal minum obat serta rutin kontrol ke Puskesmas.

Notoatmodjo menyebutkan peran petugas kesehatan sebagai komunikator diseminasi informasi, antara lain: 1) memfasilitasi masyarakat pada program pemberdayaan; 2) memberi motivasi pada masyarakat untuk bekerjasama dalam melaksanakan program kesehatan; 3) mentransfer pengetahuan, keterampilan serta teknologi pada masyarakat, agar sumber daya dapat dimanfaatkan untuk kemandirian mereka (Notoatmodjo, 2007). Kesehatan sebagai aspek penting bagi kualitas hidup seseorang. Namun belum semua orang dapat mempraktikkan usaha pemeliharaan kesehatan. Padahal jika anggota masyarakat memiliki kesadaran tentang pentingnya pemeliharaan kesehatan akan dapat membantu proses pencegahan penyakit, meningkatkan derajat kesehatannya serta berperan aktif pada setiap upaya penyelenggaraan kesehatan.

Undang-undang Nomor 36 Tahun 2009 tentang Kesehatan pada Pasal 1 disebutkan bahwa "Kesehatan adalah keadaan sehat, baik secara fisik, mental, spritual maupun sosial yang memungkinkan setiap orang untuk hidup produktif secara sosial dan ekonomis"(UndangUndang Republik Indonesia Nomor 36 Tahun 2009 Tentang Kesehatan, 2009). Sehingga dapat diketahui bahwa ukuran kesehatan tersebut tidak sekedar pada aspek fisik, mental, dan sosial, tapi juga produktivitas secara ekonomi maupun sosial.

Dari hasil pengamatan dan FGD di Desa Pakuhaji Kecamatan Ngamprah masih terdapat warga masyarakat yang belum sadar pentingnya memelihara kesehatan. Hal ini tercermin dari pernyataan salah satu informan: "saat saya sedang menyapu jalanan yang sangat kotor di depan halaman rumah seorang warga, bukan membantu malah warga itu menyebutkan sekalian aja bu dengan di dalam rumah saya".

Hal ini menandakan bahwa pengetahuan dan perilaku masyarakat mengenai kesehatan lingkungan masih dalam kategori cukup memprihatinkan. Sehingga perlu dilakukan pendekatan secara struktural melalui penegakkan kekuasaan dan kebijakan yang diperuntukkan dalam mengatur kelestarian lingkungan yang sehat.

Untuk itu, Dinas Kesehatan Bandung Barat melalui Promotor Kesehatan (Promkes) dan bidang Kesehatan lingkungan (Kesling) Puskesmas Cimareme telah aktif melakukan kegiatan promosi kesehatan dan penyuluhan terkait kesehatan lingkungan. Dalam kajian manajemen informasi dan komunikasi, upaya untuk melakukan perubahan perilaku, salah satunya dengan kegiatan literasi kesehatan sebagai bagian dari promosi kesehatan. Peneliti menemukan metode penguatan peran sumber-sumber informasi kesehatan, antara lain perpustakaan desa dan sekolah serta pentingnya jaringan informasi kesehatan yang terdiri dari pihak-pihak yang bersinggungan langsung dalam upaya perubahan perilaku masyarakat (seperti, Dinas Pemberdayaan Masyarakat Desa, Dinas Perpustakaan dan Arsip, Dinas Kesehatan, dan Dinas Pendidikan dan Kebudayaan).

Dalam Pedoman Pelaksanaan Promosi Kesehatan Daerah yang tercantum dalam Keputusan Menteri Kesehatan Nomor 1114/ Menkes/SK/VII/2005 disebutkan bahwa promosi kesehatan adalah upaya untuk meningkatkan kemampuan masyarakat melalui pembelajaran dari, oleh, untuk, dan bersama masyarakat agar mereka dapat menolong dirinya sendiri, serta mengembangkan kegiatan 
yang bersumber daya masyarakat sesuai dengan kondisi sosial budaya setempat dan didukung kebijakan publik yang memiliki wawasan kesehatan.

Selanjutnya dalam undang-undang mengenai Kesehatan pada Pasal 52 dijelaskan pulabahwa upaya pelayanankesehatan paripurna mencakup aspek promotif, preventif, kuratif, dan rehabilitatif. Tapi sekarang pelayanan kesehatan dalam pandangan masyarakat umum masih berpusat pada tindakan pengobatan serta rehabilitasi. Sehingga masih berpedoman pada paradigma sakit bukan paradigma sehat. Peningkatan kesehatan tersebut dapat diupayakan dengan kegiatan promosi kesehatan. Dengan kegiatan promosi kesehatan, tidak sekedar proses penyadaran masyarakat atau peningkatan pengetahuan masyarakat tentang kesehatan saja, tapi juga upaya bagi perubahan perilaku.

Kader PKK sebagai komunikator kesehatan yang ingin warga masyarakat sadar untuk membuang sampah pada tempatnya mampu berperan sebagai penyebar pesan, dengan menganalisis komunikan agar pesan-pesan tersebut dapat mempengaruhi masyarakat. Petugas kesehatan dibekali pengetahuan agar masyarakat sadar dari perilaku yang tidak mendukung hidup sehat.

Strategi promosi kesehatan dengan pemberdayaan akan lebih berhasil jika didukung kegiatan bina suasana sebagai upaya menciptakan lingkungan yang memicu individu, keluarga, dan masyarakat dalam mencegah penyakit, meningkatkan kesehatan,menciptakan lingkungan sehat serta aktif dalam upaya penyelenggaraan kesehatan, sebagaimana tercantum dalam Keputusan Menteri Kesehatan No. 1114/Menkes/SK/VII/2005 tentang Pedoman Pelaksanaan Promosi Kesehatan di Daerah, bahwa:

Promosi kesehatan adalah upaya untuk meningkatkan kemampuan masyarakat melalui pembelajaran dari, oleh, untuk dan bersama masyarakat, agar mereka dapat menolong diri sendiri, serta mengembangkan kegiatan yang bersumber daya masyarakat, sesuai dengan kondisi sosial budaya setempat dan didukung oleh kebijakan publik yang berwawasan kesehatan (Keputusan Menteri Kesehatan No. 1114/Menkes/SK/VII/2005 tentang Pedoman Pelaksanaan Promosi Kesehatan di Daerah, 2005).

Menolong diri sendiri yang berarti masyarakat dapat menghadapi masalahmasalah kesehatan yang mengancam dengan cara mencegahnya serta mengatasi masalah kesehatan yang sudah terjadi dengan cara menanganinya secara efektif serta efisien. Jadi masyarakat dapat memecahkan masalah kesehatan yang dihadapinya, baik masalah kesehatan yang sudah diderita maupun yang potensial (mengancam), secara mandiri (dalam batas-batas tertentu).

Untuk itu usaha menjadi anggota masyarakat yang literat informasi kesehatan menjadi hak setiap warga negara, sebagaimana pengertian literasi kesehatan menurut WHO yang dikutip Nutbeam bahwa:

Health literacy represents the cognitive and social skills which determine the motivation and ability of individuals togain access to, understand and use information in ways which promote and maintain good health... health literacy means more than being able to read pamphlets and successfully make appointments. Byimproving people's access to health information and their capacity to use it effectively, health literacy is critical to empowerment (Nutbeam, 2006).

Literasi informasi kesehatan penting bagi masyarakat, perlu pemberdayaan masyarakat yang terarah serta dukungan pemerintah secara berkelanjutan. Hal ini penting bagi peningkatan kualitas kesehatan masyarakat serta mencapai kesehatan yang paripurna, yaitu secara fisik, mental, sosial dan ekonomi. Soekijo Notoatmodjo menyebutkan masyarakat yang mampu atau mandiri di bidang kesehatan, yaitu mempunyai pengetahuan yang baik (health literacy), sebagai berikut: (1) Pengetahuan tentang penyakit, baik penyakit menular maupun tidak menular, (2) Pengetahuan tentang gizi dan makanan yang harus dikonsumsi agar tetap sehat sebagai faktor penentu kesehatan seseorang, (3) Perumahan sehat dan sanitasi dasar yang diperlukan untuk menunjang kesehatan keluarga atau masyarakat. dan (4) Pengetahuan tentang bahaya-bahaya merokok, dan zat-zat lain yang dapat menimbulkan gangguan kesehatan (Notoatmodjo, 2007) .

Sebagaimana kita ketahui kesuksesan penyebaran informasi kesehatan tergantung 
pada upaya komunikator dalam menyusun pesan agar dapat mempengaruhi perubahan sikap komunikan. Untuk tujuan masyarakat yang mandiri di bidang kesehatan sebagaimana tersebut di atas, salah satu pendekatan yang telah dilakukan dalam mengelola pesan terkait dengan isi informasi (pesan) kesehatan berupa penitikberatan (priority). Misalnya status sanitasi yang buruk diupayakan dengan penyuluhan kesehatan tentang perumahan sehat dan sanitasi dasar.

Peneliti juga terlibat aktif melakukan upaya penguatan peran perpustakaan desa dan perpustakaan sekolah dalam menunjang penyebaran informasi kesehatan lingkungan ini, dengan melakukan kegiatan Pengabdian Pada Masyarakat (PPM) pada Bulan Agustus 2018 yang mengundang para pengelola perpustakaan Desa dan Perpustakaan Sekolah di wilayah kerja Puskesmas Cimareme. Teknik yang digunakan adalah Action Group Orientation (AOG), yaitu diangkatnya 4 (empat) kasus yang diserahkan pada audiens untuk menemukan solusinya serta adanya pelibatan para pembuat kebijakan (Kasie PMD, kepala Puskesmas, kepala desa dan kaur kesra).

Dinas kesehatan memberdayakan kader pemberdaya masyarakat (KPM), yaitu para sukarelawan yang peduli pada peningkatan kualitas kesehatan sekitarnya. Kader dipilih oleh masyarakat sendiri, biasanya karena memiliki keterampilan tertentu, antara lain dapat membaca dan menulis serta aktif di tengah masyarakat. Mubarak, menyebutkan tenaga sukarela, dipilih, dipercaya, dan berasal dari masyarakat setempat, telah mengikuti pelatihan kader dibidang kesehatan sebagai pelaksana, pemelihara, dan pengembang kegiatan yang ada di masyarakat dalam upaya pembangunan kesehatan dan kesejahteraan masyarakat (Mubarak \& Sayatin, 2009).

Para kader diberi pelatihan oleh petugas kesehatan di tingkat kecamatan, dalam hal ini agar dapat mengidentifikasi faktor penyebab masalah kesehatan yang bisa bersumber pada perilaku/pengetahuan, lingkungan sosial, lingkungan fisik, lingkungan biologis atau akses ke pelayanan kesehatan. Selanjutnya dilakukan pendidikan literasi kesehatan, diupayakan terlebih dahulu peningkatan pengetahuan kader PKK dalam akses perolehan dan pemanfaatan informasi, upaya penyebarluasan informasi kesehatan serta strategi promosi kesehatan sebagai sarana edukasi.

Sumber pesan kesehatan mungkin seorang petugas kesehatan setempat atau pemerintah, atau para anggota masyarakat itu sendiri yang menginginkan perubahan. Dalam perumusan strategi diperlukan kegiatan menyusun pesan, yaitu menentukan tema dan materi. Selain itu, syarat utama dalam mempengaruhi khalayak adalah mampu membangkitkan perhatian. Komunikasi terjadi bila sebuah pesan disampaikan dan diterima. Pesan pada pendidikan kesehatan adalah sesuatu yang dianggap penting untuk diketahui atau dilakukan oleh orang dalam masyarakat.

Berkaitan dengan pesan, Wilbur memberikan kriteria-kriteria sebuah pesan dalam berkomunikasi, yaitu: (1) Pesan harus dirancang dan disampaikan semenarik mungkin sehingga pesan itu dapat mempengaruhi dan menarik perhatian sasaran, (2) Pesan harus menggunakan tanda-tanda yang tertuju pada pengalaman yang sama antara komunikator dan komunikan, (3) Pesan harus membangkitkan kebutuhan pribadi pihak komunikan dan menyarankan beberapa cara untuk memperoleh kebutuhan tersebut, (4) Pesan harus menyarankan suatu cara untuk memperoleh kebutuhan tadi yang layak bagi situasi kelompok tempat komunikan berada (Effendy, 2001).

Pesan dapat diteruskan dari orang ke orang dalam percakapan pribadi atau dalam pertemuan kelompok atau ceramah kesehatan atau dengan cara tidak langsung melalui siaran radio atau surat kabar. Sebagaimana yang dilakukan promotor kesehatan Puskesmas Cimareme dalam menghimbau warga Desa Pakuhaji untuk membuat inovasi bidang kesehatan. Promotor kesehatan sebagai bagian dari kementerian kesehatan yang membangun kualitas masyarakat melalui kesehatan, menyampaikan pesan dalam menggerakkan sumber daya masyarakat untuk sebuah proyek inovasi. Kegiatan ini akan dijadikan salah satu ujung tombak kepedulian warga terhadap kesehatan diri, keluarga dan lingkungannya. Seperti kegiatan "Deklarasi Pakuhaji Bebas Asap Rokok" pada Tanggal 2 Oktober 2017 yang ditandatangani oleh kepala desa dan perangkatnya serta tokoh masyarakat (kepala Dusun, ketua RT dan ketua RW). Hal terpenting adalah apa yang terjadi setelah pesan itu mencapai orang yang dituju. Bila mereka mendengar dan mengerti pesan tersebut serta cenderung mempercayainya, komunikasi 
yang baik telah terjadi. Sebagaimana upaya yang telah dilakukan di Desa Pakuhaji, setelah dilakukan deklarasi Pakuhaji Bebas Asap Rokok, kemudian dilakukan peresmian "Saung Nyesep" di belakang Kantor Kepala Desa Pakuhaji. Saung tempat perokok dibuat sebagai upaya mengurangi kebiasaan merokok para aparat desa dan warga yang berkunjung ke Balai Desa. Karena mulai dari gerbang masuk dan di dalam Balai Desa tidak diperkenankan untuk merokok.

Apabila khalayak telah mengetahui dan mengerti pesan serta cenderung mempercayainya, maka penyebaran informasi kesehatan yang baik telah terjadi. Hasil kegiatan penyebaran informasi diharapkan dapat merubah perilaku, meski perilaku terlalu kompleks bagi suatu perubahan. Tetapi fakta atau gagasan yang diketahui, dimengerti dan dipercaya oleh khalayak adalah perlu untuk merintis jalan bagi perubahan perilaku yang diinginkan dan peran masyarakat yang telah mendapat informasi. Sebelum melakukan komunikasi perlu dipelajari siapa yang akan menjadi khalayak komunikasi. Hal tersebut itu tergantung pada tujuan komunikasi, apakah informatif, persuasif atau instruktif. Selain itu yang utama harus dicermati adalah faktor situasi dan kondisi.

Pesan komunikasi yang disampaikan harus disesuaikan dengan kerangka referensi (frame of reference) dan lapangan pengalaman (field of experience) khalayak yang tepat. Untuk itu harus memperhatikan: (1) kondisi kepribadian dan kondisi fisik khalayak; (2) Pengaruh kelompok dan masyarakat serta nilai-nilai dan norma-norma dalam kelompok dan masyarakat yang ada; serta (3) Situasi dimana kelompok itu berada.

Dalam proses komunikasi, komunikator dan khalayak mempunyai kepentingan, diutamakan kepentingan tersebut sama agar dapat tercapai hasil yang positif. Untuk itu komunikator harus menciptakan persamaan kepentingan dengan khalayak, terutama dalam pesan, metode dan media. Untuk menciptakan persamaan kepentingan, maka komunikatornya perlu mengerti dan memahami kerangka pengalaman dan kerangka referensi khalayak secara tepat.

Data yang diperoleh melalui wawancara dengan Ibu Dian, Kasi Pemberdayaan Masyarakat Desa (PMD) Kecamatan Ngamprah disebutkan bahwa:

untuk sekarang pendirian posyandu sudah direvitalisasi dari APBD (Anggaran Pengeluaran dan Belanja Daerah). Untuk tahun 2017 ada bantuan dari Gubernur Jawa Barat. Jumlah Posyandu pada tahun 2016 sebanyak 162, sedangkan untuk tahun 2017 menjadi 164 Posyandu (Hasil Wawancara, Dian).

Adapun kegiatan yang dilakukan oleh posyandu diantaranya adalah: (1) Bina keluarga Remaja (BKR). Dikelola oleh para anggota Karang Taruna yang bekerjasama dengan UPTKB, (2) Bina Keluarga Lansia (BKL), dan (3) Pusat Informasi Konseling (PIK). Berupa penyuluhan informasi kepada sasaran kegiatan posyandu yaitu ibu balitanya dan pengantar yang menemani berangkat ke posyandu.

Selain itu program - program lainnya yang dilakukan oleh posyandu adalah:(1) Program gempungan (khusus untuk daerah Kabupaten Bandung Barat), diterapkan untuk peningkatan pemberdayaan perempuan, 2) P2WKSS (program pengentasan kemiskinan), dan 3) Desa Siaga. Salah satu yang menjadi percontohannya adalah di Desa Pakuhaji mempunyai inovasi dengan dibangun Saung Nyesep, yaitu suatu tempat khusus untuk merokok yang dibangun di kantor balai desa, 4) Warung Teknologi Tepat Guna, 5) Lomba 10 Program PKK, dan 6) Diadakan musyawarah dusun $\rightarrow$ RKPDes $\rightarrow$ menuju APBDes

Notoatmodjo (2007) menyebutkan perilaku kesehatan dapat diklasifikasikan menjadi 3 kelompok, yaitu: (1) Perilaku pemeliharaan kesehatan (health maintance), yaitu perilakuperilaku atau usaha-usaha seseorang untuk memelihara atau menjaga kesehatan agar tidak sakit dan usaha untuk penyembuhan bila sakit, (2) Perilaku pencarian dan penggunaan sistem atau fasilitas pelayanan kesehatan, atau sering disebut perilaku pencarian pengobatan (health seeking behavior), yaitu upaya atau tindakan seseorang saat menderita sakit dan atau kecelakaan, (3) Perilaku kesehatan lingkungan yaitu bagaimana seseorang merespons lingkungan, baik lingkungan fisik maupun sosial budaya dan sebagainya, sehingga lingkungan tersebut tidak mempengaruhi kesehatannya.

Saparinah menggambarkan hubungan individu dengan lingkungan sosial saling memengaruhi (Notoatmodjo, 2007). 
kesehatan lingkungan di Desa Pakuhaji perlu diidentifikasi keterkaitannya dengan masalah perilaku yang memengaruhi masalah kesehatan, masalah lingkungan fisik dan sosial yang dapat mempengaruhi perilaku, status kesehatan dan kualitas hidup seseorang atau masyarakat. Merujuk fungsi Puskesmas dalam Surat Keputusan Nomor 128/Menkes/ SK/II/2004 tentang Kebijakan Dasar Pusat Kesehatan Masyarakat, antara lain puskesmas sebagai pusat pemberdayaan masyarakat. Puskesmas berupaya agar perorangan terutama pemuka masyarakat, keluarga dan masyarakat termasuk dunia usaha memiliki kesadaran, kemauan, dan kemampuan melayani diri sendiri dan masyarakat untuk hidup sehat, berperan aktif dalam memperjuangkan kepentingan kesehatan termasuk pembiayaannya, serta ikut menetapkan, menyelenggarakan dan memantau pelaksanaan program kesehatan dengan memperhatikan kondisi dan situasi, khususnya sosial budaya masyarakat setempat, keadaan penerima informasi (sosiodemografi) serta konteks dilakukannya komunikasi.

Agardapatmemperluas pengetahuan bidang kesehatan, warga masyarakat dapat merujuk pada berbagai sumber informasi kesehatan. Saat ini banyak poster, buku, situs internet, maupun seminar-seminar ilmiah yang menawarkan berbagai informasi kesehatan sehingga masyarakat dapat memperoleh pengetahuan dasar bidang kesehatan. Sebagaimana yang dilakukan oleh promotor kesehatan dalam menyampaikan informasi kesehatan dilakukan secara berjenjang hingga mencapai khalayak sasaran, antara lain melalui grup media sosial WhatsApp (WA). Anggota grup WA adalah promotor kesehatan, bidan desa, ketua desa siaga, ketua tim penggerak PKK tingkat desa. Dari merekalah kemudian informasi kesehatan, baik yang bersifat informatif maupun persuasif menyebar ke khalayak desa secara luas.

Dalam menjalankan peran sebagai fasilitator, motivator dan mediator ini dukungan dari pemegang kebijakan, baik bidang promosi kesehatan tingkat kabupaten, Camat, Kepala Seksi Pemberdayaan Masyarakat Desa, serta para perangkat desa berperan besar dalam terselenggaranya pemberdayaan masyarakat dalam diseminasi informasi kesehatan. Begitupula pimpinan non formal, seperti tokoh masyarakat (tertua) dan pimpinan pesantren yang kadangkala menyelipkan informasi kesehatan dalam materi ceramah atau nasihatnya agar warga masyarakat dapat meningkatkan kualitas kesehatannya, seperti dengan menjaga kebersihan sebagai bagian dari tuntunan agama. Komitmen membangun kemandirian warga bidang kesehatan ini perlu dimiliki oleh semua lapisan yang peduli dengan keharmonisan lingkungan serta kualitas hidup warganya. Hingga komunikator bidang kesehatan ini tidak terbatas pada mereka-mereka yang mempunyai wewenang, namun diharapkan ke depan setiap warga masyarakat, khususnya di Desa Pakuhaji Kecamatan Ngamprah, dapat menjalankan peran sebagai komunikator.

Diseminasi informasi kesehatan subbidang pemberdayaan masyarakat mengehendaki adanya partisipasi aktif anggota masyarakat dalam memecahkan masalah kesehatan mereka. Dalam hal ini, masyarakat sendirilah yang aktif memikirkan, merencanakan, melaksanakan dan mengevaluasikan program-program kesehatan. Hal ini didukung hasil kajian Komariah, Perbawasari \& Budiana, yang menyatakan bahwa pelayanan pemberian informasi secara linier dapat meningkatkan tingkat pengetahuan masyarakat (pasien) (Komariah, Perbawasari, Nugraha, \& Budiana, 2013). Institusi kesehatan hanya sekedar memotivasi dan membimbingnya. Untuk itu merupakan hal yang menggembirakan dengan adanya output pemberdayaan masyarakat, seperti: Deklarasi Pakuhaji Bebas Asap Rokok, dibangunnya Saung Nyesep pengkondisian para perokok untuk mengurangi kebiasaan merokok di lingkungan kantor kepala desa dan meningkatnya salah satu posyandu di Desa Pakuhaji dari Posyandu aktif menjadi Posyandu Mandiri.

Meskipun dari tingkat pendidikan, warga masyarakat Desa Pakuhaji belum mencapai taraf pendidikan yang optimal, namun berdasarkan hasil observasi dan wawancara lapangan, umumnya warga masyarakat mengikuti dengan baik baik program-program kesehatan dari pemerintah dalam upaya meningkatkan kualitas kesehatan, seperti adanya Pekan Imunisasi Nasional MR (Mums dan Rubella) lalu. Hanya satu keluarga yang menolak mendapatkan imunisasi. Dari hasil wawancara dengan Ibu Inang, Bidan Desa Pakuhaji diperoleh data bahwa keengganan keluarga tersebut memvaksin anaknya karena alasan agama (mengandung zat yang haram dikonsumsi) dan dituangkan dalam surat pernyataan bermaterai. 
Kemandirian masyarakat di bidang kesehatan sebagai hasil pemberdayaan di bidang kesehatan sesungguhnya sebagai wujud dari tanggungjawab masyarakat agar hak kesehatan mereka terpenuhi. Hak-hak kesehatan masyarakat adalah hak untuk dilindungi dan dipeliharanya kesehatan mereka oleh dirinya sendiri, tanpa tergantung pada pihak lain. Yusup dan Komariah menyatakan bahwa selalu ada kebutuhan, ada tindakan dan ada pilihan terhadap informasi dan sumbersumber informasi kesehatan pada setiap orang, baik dalam kedudukannya secara personal individual maupun sebagai anggota keluarga dan masyarakat secara lebih luas (Yusup \& Komariah, 2018). Hasil penelitian tentang Diseminasi Informasi Kesehatan Masyarakat Pedesaan menghasilkan model yang ditunjukkan oleh gambar 3 .

\section{SIMPULAN}

Kepala desa, petugas kesehatan dari kecamatan, bidan desa dan kader posyandu sebagai motor penggerak (agen pemberdaya) pemberdayaan kesehatan dalam menyampaikan beragam informasi kesehatan pada masyarakat di Desa Pakuhaji. Dalam pengorganisasiannya melibatkan berbagai pihak dengan sistem pemberdayaan berjenjang, hingga subjek akhirnya adalah warga masyarakat. Agen pemberdaya sebagai komunikator diseminasi informasi menjalankan peran sebagai fasilitator, motivator dan mediator didukung para pemimpin masyarakat, baik formal maupun informal. Hingga dalam menjalankan komitmennya membangun kemandirian warga mendapat dukungan, perhatian serta masukannya secara sukarela diikuti masyarakat. Sedangkan petugas kesehatan melakukan strategi manajemen pesan berupa pendidikan dan promosi kesehatan dengan penyampaian informasi kesehatan untuk perubahan perilaku yang berwawasan kesehatan melalui sosialisasi dan penyuluhan pada perangkat desa dan warga masyarakat. Selain itu memberikan informasi yang bersifat ajakan (persuasif) agar masyarakat dapat meningkatkan kualitas kesehatannya. Diseminasi informasi akan berhasil apabila komunikator dapat menganalisa khalayaknya, dalam hal ini komunikator mengidentifikasi berdasarkan sosiodemografi, kebutuhan informasi kesehatan serta cara-cara pemilihan akses informasi

Khalayak dalam diseminasi informasi kesehatan memiliki ragam aspek sosiodemografi, kebutuhan yang perlu dipenuhi serta akses kesehatan yang berbeda pula.

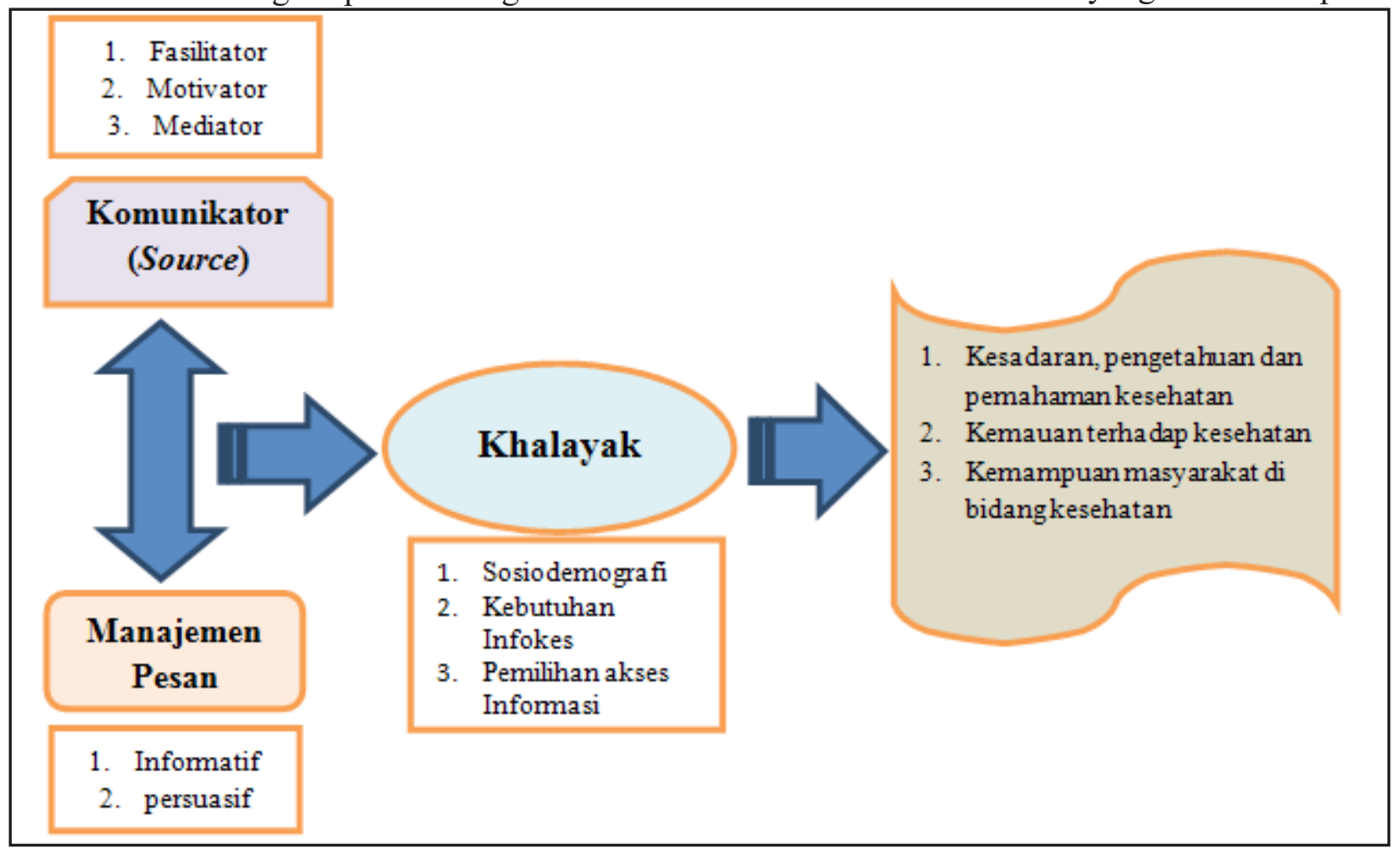

Sumber: Hasil penelitian 2017 
Dengan upaya promosi kesehatan yang dimotori oleh Puskesmas Cimareme dan pemberdayaan masyarakat melalui literasi kesehatan, diharapkan masyarakat dapat mandiri di bidang kesehatan

\section{DAFTAR PUSTAKA}

Effendy, O. U. (2001). Ilmu, teori dan filsafat komunikasi. Bandung: Citra Karya.

Hamad, I. (2007). Konstruksi realitas politik dalam media. Jakarta: Granit.

Irianto, K. (2014). Ilmu kesehatan masyarakat. Bandung: Alfabeta.

Keputusan Menteri Kesehatan No. 1114/ Menkes/SK/VII/2005 tentang Pedoman Pelaksanaan Promosi Kesehatan di Daerah (2005). Indonesia. Retrieved from http:// www.depkes.go.id/resources/download/ promosi-kesehatan/pedoman-pelaksanaanpromosi-kesehatan-di-puskesmas.pdf

Komariah, K., Perbawasari,S., Nugraha,A.R., \& Budiana, H.R. (2013). Pola komunikasi kesehatan dalam pelayanan dan pemberian informasi mengenai penyakit tbc pada puskesmas di kabupaten bogor. Jurnal Kajian Komunikasi, 1(2))), 173-185

Laksono, A. D., \& Wulandari, R. D. (2011). Analisis potensi penyebaran informasi kesehatan melalui jejaring sosial: studi kasus pada forum jejaring peduli aids. Buletin Pnelitian Sistem Kesehatan, 14(4), 358-365. Retrieved from http://ejournal. litbang.depkes.go.id/index.php/hsr/article/ view/1373/2197

Liliweri, A. (2013). Dasar-dasar komunikasi kesehatan. Yogyakarta: Pustaka Pelajar.

Mubarak, W, I \& Chayatin, N. (2009). Ilmu keperawatan komunitas pengantar dan teori. Jakarta: Salemba Medika.

Niftah, Y.Z, \& Rahmat, A (2009) Pengaruh kredibilitas konselor terhadap sikap remaja mengenai hiv/aids di Sukabumi. Jurnal
Kajian Komunikasi. 5(2), 159-167

Notoadmojo, S. (2007). Promosi kesehatan dan ilmu perilaku. Jakarta: Rineka Cipta.

Nutbeam, D. (2006). Health literacy as a public health goal ; a challenge for contemporary health education and communication strategies into the 21 st century. Health Promotion International, 15(3), 264.

Ratnasari, A. (2008). Komunikasi kesehatan: penyebaran informasi gaya hidup sehat. Mediator: Jurnal Komunikasi, 9(1), 1-12. Retrieved from https://ejournal. unisba.ac.id/index.php/mediator/article/ view/1136/694

Rodiah, S., Rosfiantika, E., \& Yanto, A. (2016). Strategi promosi kesehatan puskesmas dtp tarogong kabupaten garut. Sosiohumaniora, 18(1), 1-12. Retrieved from http://jurnal. unpad.ac.id/sosiohumaniora/article/ view $/ 9357 / 6341$

Soekijo, N. (2007). Promosi kesehatan dan ilmu perilaku. Jakarta: Rineka Cipta.

Sugiyono. (2010). Metode penelitian kuantitatif, kualitatif dan $r \& d$. Bandung: Alfabeta.

Undang-undang republik indonesia nomor 36 tahun 2009 tentang kesehatan, Pub. L. No. 36, http://sireka.pom.go.id (2009). Indonesia. Retrieved from http://sireka. pom.go.id/requirement/UU-36-2009Kesehatan.pdf

Wahyudi, U. (2009). Membangun komunikasi kesehatan di jawa barat. Jurnal Observasi Komunikasi Kesehatan. Observasi Komunikasi Kesehatan, 7(1), 1-10.

Yin, R. K. (2008). Studi kasus: desain dan metode. (Mudzakir, Ed.) (8th ed.). Jakarta: Raja Grafindo Persada.

Yusup, P. M., \& Komariah, N. (2018). Penggunaan sumber-sumber informasi kesehatan di kalangan penduduk miskin pedesaan. in komunikasi kesehatan: pemikiran dan penelitian. Bandung: Remaja Rosdakarya. 